\title{
Legal Protection for Plant Intellectual Property
}

\author{
Robert J. Jondle
}

Additional index words. utility patents, plant patents, plant variety protection, breeders' rights, trade secrets

Summary. An overview of current legal options for the protection of plant innovations is presented. Plant protection options vary from country to country, depending on the type of plant invention-e.g., a new biotechnology method, a gene, plant cultivar, or hybrid. Plant science, plant breeding, and biotechnology are interconnected and international in scope. Therefore, it is important to consider international plant protection options available for plant innovations.

$\mathrm{T}$ he development of new plant innovations by either private or public plant breeders and biotechnologists involves considerable research and development expenses. Each year, private companies invest hundreds of millions of dollars in biotechnology and plant breeding research. Effective protection of these new plant products is necessary to provide an incentive to make this large research investment. Universities also are selectively protecting certain plant research products to encourage technology transfer from the university to private industry or to increase resources for research.

Unfortunately, there is a lack of harmony in world-wide intellectual property law regarding plant innovations. The confusing array of options available from country to country causes much debate and concern by private organizations as to whether these organizations may obtain reasonable returns on plant research investments. Public institutions are concerned with how the evolving and increasing plant proprietary rights will affect their research programs and the availability of germplasm.

This article focuses on 1) utility patents, 2) breeders' rights, and 3) trade secret law. I also discuss the issues of 1) lack of uniformity in world-wide patent proprietary rights, and 2) development of strategies for obtaining and/or dealing with plant proprietary rights.

Henderson é Sturm, Omaba, Neb.

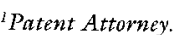

\section{A brief history}

Prior to 1940 , public institutions were the primary developers of new cultivars for nearly all crop species. By the 1940s, the development of corn hybrids and certain horticultural crops began moving to the private sector. Private seed companies focused on the research and development of new hybrid cultivars, primarily corn and sorghum, which had a "built-in" form of protection under trade secret law. The parental lines of the hybrids could be held as trade secrets, as long as there was no public disclosure.

After breeders' rights and plant variety protection laws were enacted, private research and development in other crops, such as soybeans andwheat, expanded rapidly (Lerch, 1989). Over the past 20 years, the trend in public research has been to emphasize germplasm enhancement, basic plant research, and new biotechnology techniques and to deemphasize or discontinue cultivar development.

Multiple types of plant protection options vary from country to country, and include the primary categories of utility patents; breeders' rights, including the International Union for the Protection of New Varieties of Plants (UPOV) and Plant Variety Protection Act (PVP) for the United States; trade secrets; and contract law. The owner of a plant invention should carefully review and assess the various options that are available in each country.

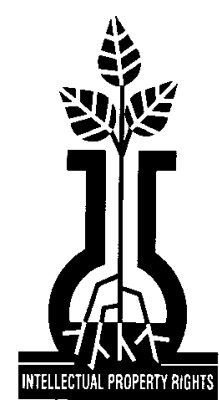

$\int$ ublic insticoncerned with how the evolving and increasing plant proprietary rights will affect their research programs and the availability of germplasm. 


\section{Utility patents}

Utility patent laws were enacted to promote progress in the useful arts by granting inventors the exclusive right to their discoveries for a limited period or time. Utility patent applications can be flexible in subject matter and broader in scope than breeders' rights, which cover only new plant cultivars (Jondle, 1989). For example, in the United States, utility patents provide protection to "any new and useful manufacture, or composition of matter, or any new and useful improvement thereof" (35 USC 101), which includes proteins, genes, gene fragments, DNA, RNA, microorganisms, transformed cells, plants, plant parts (seeds, pollen, fruit, flowers), plant cultivars, hybrids, and chemicals, as well as the processes of making any of the foregoing.

The claims of a patent define the scope of the protection available to the patent holder. One patent theoretically can have as many claims as the inventor wishes, and the Patent Office allows, but, generally, the average number of claims for an issued patent ranges from 10 to 60 .

Utility patent protection is available for biotechnology processes and genes in most European countries, the United States, and Japan. Utility patent protection for plant cultivars per se is currently available in the United States, Mexico, and Hungary, based on their respective national patent laws.

\section{The United States}

In the United States, court decisions in Diamond v. Chakrabarty and In re Hibberd have established that the statutory subject matter for utility patents includes "everything under the sun that is made by man." Therefore, any new plant innovations that meet the requirements ofnovelty, utility, and non-obviousness are eligible for utility patent protection. U.S. patents have been issued for plant inbreds, hybrids, plant parts, biotechnology methods, genes, and many other plant innovations.

\section{The European Patent Convention}

Plant researchers can apply for utility patent protection on their newly developed cultivars, inbreds, and hybrids in the United States, Mexico, and Hungary. In contrast, the current policy of the European Patent Office (EPO) is that plant cultivars and hybrids per se are not patentable subject matter. The European Patent Convention (EPC) includes 14 countries: Greece, Ireland, Italy, Belgium, France, Austria, Germany, Great Britain, Luxembourg, Netherlands, Sweden, Switzerland, Liechtenstein, and Denmark.

The EPO will grant utility patents on microorganisms per se, on biotechnology processes such as insertion of a desired gene into a plant species, or on a gene that can be inserted in many different plant cultivars. The first clause of EPC Article 53(b) excludes protection for plant cultivars per se. Plants containing a gene produced via genetic engineering are patentable. The EPO states that the purpose of Article 53(b) is to exclude from patent protection matter that is eligible for protection under the legislation on the protection of plant cultivars (UPOV). Prior to the 1991 UPOV Convention, UPOV rules did not allow a country to have multiple forms of protection for plant cultivars. An exception was allowed for the United States, because the 1930 Plant Patent Act was already in existence in the United States.

Interestingly, the 1991 UPOV Convention now specifically allows multiple protection options for plants. Whether the EPC will be modified to remove the exclusion for plants or not is uncertain.

EPC Article 53(b) also excludes from patentability those biological processes that are directed to the production of plants and animals. The purpose of this provision is to exclude from plant protection activities of plant or animal breeders in the traditional (conventional breeding) sense and the products produced. Biological processes for purposes other than producing plants or animals are patentable. Non-biological processes involving plants are patentable. The EPO has determined that any method of genetic engineering is non-biological or "technical." Therefore, any method of genetic engineering is potentially patentable.

\section{Other selected countries--examples}

In the past decade, plant protection and utility patent laws for plant innovations have been changing and evolving in many countries. Specific examples (for selected countries) ofvariations in the laws are given below.

Argentina. Current policy in Argentina is to refuse applications for plant cultivars, pure cultures of "naturally existing" microorganisms, and for plant cells and genetically engineered plants. The Argentine Patent Office does accept applications for genetically engineered microorganisms and microorganism processes.

Australia. Australian Patent Office practice appears to permit patent protection for all categories of biotechnology, including pure cultures of a naturally existing microorganism. The Australian Patent Office has described its policy in this regard in the following terms: "The criteria to be met before an application concerned with living organisms will be accepted are precisely the same as those for any other application, i.e., 
no distinction is to be made solely on the basis that a claimed product or process is, or contains or uses, a living organism. Higher life forms will not be treated any differently from lower life forms such as microorganisms."

"The only criteria having particular significance in relation to living organisms is the requirement of Section 40 of the Patents Act concerning a full description of the best method of performing the invention. In this regard, it should be noted that disclosure of a method of performing the invention, i.e., producing a new organism, which by repetition will again produce the organism, is required."

The Australian Patent Office issued patents to new plant cultivars prior to becoming a member of the 1978 UPOV Convention (Bent, 1987).

Brazil. Brazilian Patent Law, in Article 9(f), has been interpreted broadly to exclude most biotechnology inventions and plant cultivars. Plants formerly were considered patentable under a law enacted in 1969, but, under the 1971 law, plants are prohibited from protection.

Canada. Microbiological processes may be patented. In a recent court case, the Canadian Supreme Court decided that no patent for a soybean cultivar could be granted because the patent specification did not comply with the disclosure requirements of the Canadian Patent Act.

Chile. The Chilean Patent Office interprets the law to allow as patentable only methods for obtaining a specific biological result.

Japan Microbiological processes and products obtained from these processes are patentable. Japanese Patent Office policy is to allow patent protection for processes for developing plant cultivars, but not for the plant cultivars per se. Plant cultivars are protected under the Seed and Seedlings law.

Mexico. As of July 1991, Mexico allows utility patents to be granted for biotechnology inventions, plant varieties, and microbes. However, patents will not be granted for vegetable or animal species, or for animal genes or parts of the human body. The patent protection lasts for 20 years from the application date.

Mexican Seed Law Article 20 states that the following are considered patentable:

-plant varieties

-inventions relative to microorganisms

-biotechnological processes for obtaining pharmaceuticals, medicines in general, drinks, foods (etc.).

In addition, Article 20 of the Mexican Seed Law lists the following as non-patentable subject matter:

-processes that are essentially biological for obtaining or for the reproduction of plants,...including genetic or other processes related to material that is capable of causing its own duplication

-vegetable species and animal species or breeds -biological material as it is found in nature -genetic material

-inventions related to living matter that makes up the human body.

In summary, the utility patent laws as they relate to plant innovations have been evolving in many countries over the past 3 decades. Prior to 1980 , the utility patent laws were designed primarily to handle mechanical, electrical, and chemical arts and biological organisms, except that microorganisms often were viewed as non-patentable. It was this viewpoint that prompted the enactment of breeders' rights regulations.

The 1961, 1972, and 1978 breeders' rights (UPOV) conventions prohibited double types of protection for plant cultivars and had a major impact on the utility patent laws drafted after 1961 in most European countries, and all countries (other than the United States and Hungary) that have joined these UPOV conventions. The 1991 UPOV convention allows multiple types of plant protection where each country decides for itself which types of plant protection it will use.

\section{Breeders' rights (UPOV), seed registrations}

The purpose of the UPOV convention and seed registration laws ofcertain countries is to recognize and ensure to the breeder of a new plant cultivar certain rights regarding the use by others of the protected cultivar.

\section{Breeders' rights (the UPOV)}

The International Convention for the Protection of New Varieties of Plants (the UPOV) was concluded in 1961, and was revised in 1972, 1978, and 1991.

Article 2(1) of the original 1961 UPOV Convention permitted each member state the option to provide protection rights to new cultivars by grant of either a special title of protection or a patent, but required a member state to provide only one of these forms for one botanical genus or species. Over the next 2 decades, countries that enacted breeders' rights legislation implemented the UPOV Convention, which prohibited having protection by both patent and breeders' rights. The United States was exempt from this requirement, having previously enacted the 1930 Plant Patent Act.

At present, there are 22 member states in the UPOV. Member States for Breeder's Rights (the 1978 Act) include the following:
$7 \Gamma$ he utility patent laws as they relate to plant innovations have been evolving in many countries over the past 3 decades. 
ne weak-
ness of the U.S. Plant Variety Protection Act (the PVPA) is the Farmers'

Exemption (113), which, under one interpretation of the statute, allows a farmer to sell up to, but less than, $50 \%$ of his or her harpested crop of a protected cultivar to other farmers for planting purposes.
Argentina, Australia, Canada, Czechoslovakia, Denmark, France, Germany, Hungary, Ireland, Israel, Italy, Japan, Netherlands, New Zealand, Poland, South Africa, Sweden, Switzerland, the United Kingdom, and the United States. Belgium and Spain are members of the 1961 UPOV Convention.

\section{The U.S. Plant Variety Protection Act}

One weakness of the U.S. Plant Variety Protection Act (the PVPA) is the Farmers' Exemption (113), which, under one interpretation of the statute, allows a farmer to sell up to, but less than, $50 \%$ of his or her harvested crop of a protected cultivar to other farmers for planting purposes. On 30 Sept. 1991, the U.S. District Court for the Northern District of Iowa, in Asgrow Seed Co. V. W interboer; specified a quantitative limit on the amount of farmer-saved seed under 113, commonly called the "farmers' exemption." This quantitative limit would allow a farmer to save and sell to other farmers, for planting purposes only, that amount of seed that he or she could reasonably expect to use for his or her own planting purposes the following growing season. Defendants Winterboer appealed to the Court of Appeals for the Federal Circuit. The Federal Circuit reversed the district court decision and remanded the case back to the district court for reconsideration.

\section{Selected countries-examples}

Argentina. Argentina has plant variety protection laws, but is not a member of the UPOV. The Argentina Seed and Phytogentical Creations Law protects registered seeds, including fruits, bulbs, tubers, buds, cuttings, and nursery plants. The new cultivar must meet the requirements of distinctiveness, uniformity, and stability. Length of protection varies depending on the species, and ranges from 10 to 20 years.

Canada. On 6 Nov. 1991, regulations for the Canadian Breeder's Rights Act were published. Applications for plant breeders' rights can be filed for six species, including soybeans, wheat, potato, rose, chrysanthemum, and Brassica. The cost to receive breeders' rights is about $\$ 1650$ per cultivar, and duration of the rights is 18 years. Additionally, compulsory licenses may be granted. If the holder unreasonably refuses to allow others to sell the protected cultivar, or limits distribution, charges very high prices or royalty rates, or does not maintain the quality of the cultivar, anyone adversely affected by the actions of the holder of the right may apply to the commissioner for a compulsory license.

Chile. The Chilean seed registration law provides for the registration of cultivars that are new, stable, and homogeneous. The owner of a registered cultivar has the exclusive right to produce and trade the seed of that cultivar, and no other party may use the seed without authorization.

Japan. Plant cultivars per se are protected under the Seed and Seedlings Law, which formed the basis for accession to the 1978 UPOV Convention in 1982.

\section{The 1991 UPOV Convention (breeders' rights)}

On 19 Mar. 1991, the UPOV adopted a new convention, with significant changes from the 1978 Convention (Jondle, 1992). Compared to the 1978 Convention, the 1991 UPOV Convention offers important modifications in the areas of:

-Longer duration of protection

-Limiting the use of farm-saved seed

-Rights over harvested material and their direct products

-Allowing multiple types of protection -Adopting a concept of "essentially derived" varieties.

Duration of protection. The duration of protection is increased from a minimum of 15 years to a minimum of 20 years for most species. Protection for trees and vines also is increased from a minimum of 18 years to a minimum of 25 years.

Limit to use of farm-saved seed. A second important modification in the 1991 Convention is to limit the use of farm-saved seed. A farmer may use saved seed of a protected variety to plant only on his or her own holdings. A farmer's "holding" is defined as land that is owned, rented, or leased by the farmer. Also, farmers are not permitted to sell seed to other farmers for propagating purposes. In the United States, the PVP Act needs to be amended by Congress to delete the provision authorizing the sale of saved seed.

Rights over harvested material. Another provision of the 1991 Convention provides breeders' rights over harvested material when 1) the seed is obtained without authorization of the breeder, and 2) the breeder has no reasonable opportunity to exercise his or her right. This provision does not apply to farm-saved seed. Also, as an optional provision, a breeder may have rights over products made directly from harvested material of protected lines. For example, seed of protected wheat variety may be produced without authorization of the breeder and then used to produce flour and bread. The owner of the breeders' rights certificate could enforce his or her proprietary rights against the flour or the bread in a country that has enacted legislation containing the 1991 UPOV Convention. Both of these provisions potentially 
would affect the importing ofprotected seed, or the products directly derived from harvested protected seed, from countries that do not have breeders' rights into countries that do have these rights.

Multiple types of protection allowed. The 1991 Convention allows multiple types of plant protection where each country decides for itselfwhich types of plant protection it will use. The new Convention abandons the prohibition of "double protection," which is present in the 1978 Convention. The United States was excepted from this provision because patents for asexually reproduced plants under the 1930 Plant Patent Act were available in the United States at the time the Convention was finalized. Plants also can receive utility patent protection in the United States, and there has been some concern that this would not conform with the exception to the 1978 Convention, This problem is eliminated in the 1991 Convention, which allows the United States and all member countries to decide which forms of plant protection options to use, and it allows multiple plant protections (i.e., PVP certificates, plant patents for asexually reproduced plants, and utility patents).

“Essentially derived" varieties. The concept of essentially derived varieties has been included in the 1991 Convention. For a new variety to be essentially derived, the variety must be derived from at least one protected variety. For example, if none of the parents of a new line are protected, then any new line derived from these unprotected parents will not be essentially derived from an initial protected variety when:

- the new cultivar has been predominately derived from the initial cultivar

-the new cultivar is clearly distinguishable from the initial cultivar

-the new cultivar conforms to the initial variety in the expression of the essential characteristics.

In contrast, the concept of "minimum distance" looks at how closely two varieties are similar and ignores the issue ofwhether or not the initial parental lines are protected. An essentially derived variety is still eligible for protection, but permission is required from the breeder of the initial variety in order to market the variety. Also, the determination of whether a variety is essentially derived will not be part of the decision as to whether to grant breeders' rights.

Examples of methods that may result in an essentially derived cultivars, which are listed in the 1991 UPOV Convention, are: -selection (from plants of the initial variety) of:

a) a natural or induced mutant,

b) a somaclonal variant, or c) a variant individual

-backcrossing

-transformation by genetic engineering.

Proposed ASTA definition. The American Seed Trade Assn. (ASTA) has proposed a definition of "essentially derived" as follows:

"A new variety should be considered to be essentially derived from a protected variety if, in view of its characteristics and method of development, it would be considered by a plant breeder of ordinary skill in the species to have incorporated in the new variety essentially the entire genotype of the protected variety. Factors to be considered in evaluating the method of development should include the sources of germplasm used and the breeding methods employed, including the reasonably expected results of those methods."

"Varieties that are essentially derived but nonetheless clearly distinguishable from existing protected varieties qualify for legal protection but should only be commercialized with the consent of the owner of the original variety."

ASTA strongly supports the use of the language "plant breeder of ordinary skill in the species" in determining whether or not a variety is essentially derived. Assinsel (the International Assn. of Plant Breeders for the Protection of Plant Varieties) has a working document on the definition of "essentially derived."

\section{Trade secrets}

In addition to utility patents and breeders' rights, a third important type of legal protection is by trade secret. Trade secret laws also are called "confidential information" or "know-how" in various countries. Trade secrets can provide protection for a certain technology that is never disclosed to the public, or temporary protection prior to disclosing the technology in a patent application (Ihnen, 1989).

A trade secret can include any information, process, or germplasm that gives an owner competitive advantage. The trade secret must be held secret and confidential. Trade secret law is important to all researchers, including public researchers, who may wish to obtain utility patents. Most European countries, Japan, and others, require that the invention not be disclosed publicly prior to filing of the patent application. Therefore, in order to obtain patent rights, the invention must be kept secret until the filing date of the patent application.

There are no international treaties that govern protection of trade secrets. Therefore, each country's law regarding "trade
$A \begin{aligned} & \text { trade secret } \\ & \text { can include }\end{aligned}$ any information, process, or germplasm that gives an owner competitive advantage. 
$\mathbf{R}_{\text {are shilled }}^{\text {esearch }}$ at developing new plant innovations, but are often unsure of whether or not to obtain any property rights, and which rights to obtain. secrets," "know-how," and "confidential information" will be decided by individual national law or, in the case of the United States, by individual state laws.

Secrecy. The level of secrecy required before trade secret protection is available varies considerably from country to country. For example, in the United States, in a majority of state jurisdictions, the definition of a trade secret in part, is as follows: [a trade secret]...may consist of any formula, pattern, device, or compilation of information which is used in one's business, and that gives him or her an opportunity to obtain an advantage over competitors who do not know or use it. It may be a formula for a chemical compound; a process of manufacturing, treating, or preserving materials; a pattern for a machine or other device; or a list of customers.

This definition prevails in the majority of state jurisdictions, and has been adopted by the U.S. Supreme Court. According to the Restatement definition, in order to qualify as a trade secret, information must i) be used in one's business, ii) provide a competitive advantage, and iii) be secret.

Use and competitive advantage requirements are arbitrary at best, but the secrecy requirement must be met without exception. In general, if subject matter is not actually secret, it will not be protectable as a trade secret. Comment b, Section 757 of the Restatement sets forth the most frequently cited standard for secrecy, and states, in part, that:

"The subject matter of a trade secret must be secret, Matters of public knowledge or of general knowledge in an industry cannot be appropriated by one as his secret. Matters which are completely disclosed by the goods which one markets cannot be his secret. Substantially, a trade secret is known only in the particular business in which it is used. It is not requisite that only the proprietor of the business know it. He may, without losing his protection, communicate it to employees involved in its use. He may likewise communicate it to others pledged to secrecy. Others may also know of it independently, as, for example, when they have discovered the process or formula by independent invention and are keeping it secret. Nevertheless, a substantial element ofsecrecy must exist so that, except by the use of improper means, there would be difficulty in acquiring the information."

A trade secret has only to be maintained in relative secrecy. The secrecy does not have to be absolute; i.e., known only to its owner. The secrecy must be considered to be reasonable, and in essence to be such that the trade secret is confided only in those who need to know in order to commercially exploit it. It may be necessary to disclose a trade secret to employees, contractors, suppliers, conventurers, and the like to use the trade secret commercially. However, any disclosure should be confidential, or made under conditions that imply confidentiality.

Trade secret law affords legal remedies to people whose trade secrets are misappropriated when it is acquired by improper means or disclosed in violation of a confidential relationship. Improper means includes theft, bribery, misrepresentation, and breach or inducement of a breach of duty to maintain secrecy or from a breach of contract.

\section{Issues}

Two important issues involving plant intellectual property rights are 1) the complex array of protection options available world-wide, and 2) the importance for organizations, countries, and institutions to keep informed and to address intellectual property rights.

Research staff are skilled at developing new plant innovations, but are often unsure of whether or not to obtain any property rights, and which rights to obtain. The availability of exclusive rights to a plant invention often determines whether or not the invention will be commercialized successfully.

\section{A complex array of protection options}

As was discussed in the section on utility patents, a complex array of plant intellectual property rights is available. For private organizations, it is important first to review carefully which countries have the most market potential, and second, to determine which countries have reasonably effective intellectual property rights. For public organizations, it is often important to encourage either transfer of the technology to other institutions or to commercialize it.

The present lack of harmony in plant intellectual property rights produces a confusing and complex situation for administrators and researchers in determining what protection is available in each country and how strong the protection will. be. Private biotechnology companies are spending millions of dollars each year on research and development, and they must be able to recover their research costs. Otherwise, the incentive for research and development will disappear.

Under debate at present are three major initiatives regarding the patenting of plants, including TRIPS/GATT, NAFTA, and the EC directive on legal protection.

The TRIPS (Trade Related Aspects of Intellectual Property) draft agreement presently allows plants to be excluded by member 
countries to a GATT agreement. This optional exclusion of plants from patentability is a major concern to private companies. The North American Free Trade Agreement (NAFTA) negotiation also allows the optional exclusion of the patentability ofplants. The final decisions on these agreements will have an impact on plant research. The more international uniformity in allowing plants to be patentable subject matter, the greater the incentive for plant research and development.

Ideally, to encourage support for plant biotechnology research and development of new plant varieties, both utility patent protection and breeders' rights protection need to be available in as many countries as possible. For plant varieties per se, both utility patent protection and/or breeders' rights protection should be available, as provided for in the 1991 UPOV Convention. Plant varieties that reach the higher requirements of non-obviousness or inventive step should be patentable. Some form of breeders' rights also should be available in many countries for providing plant breeders protection for plant cultivars that meet the less-exacting standards of breeders' rights law.

\section{Development strategies}

The second important area is the development of strategies for dealing with plant intellectual property rights. Each institution, organization, and country needs to keep informed of the evolution of plant protection options and address and plan for resolving property rights issues.

Government and academic administrators need to consider how to transfer most appropriately new technology to the commercial environment. Who will decide which innovations will be protected, and with which type of protection? Will an exclusive license be required to encourage commercialization of the invention, or will a non-exclusive license (or even no license) be equally effective? How much revenue can be generated for university research resources? How will public and private supporters of universities and the government react to this approach to generating additional monies? What are the best ways to maintain the primary goals of a public institution in this new age of plant proprietary rights? How are we to deal with the intellectual property rights of other organizations? These questions and many others need to be discussed and debated, and decisions must be made for each individual organization.

Private organizations are concerned with obtaining a fair return on their research investments. For each type of plant innovation, decisions must be made as to which form of protection is best (e.g., trade secret, utility patent, license, breeders' rights, etc.). Also, decisions must be made concerning the countries in which protection should be pursued and whether adequate protection and enforcement can be obtained in those countries. Part of the planning for new research projects should include the potential property rights that can be developed, and how strong the protection is for these property rights. If there is limited potential return on a research investment, there is more risk and less incentive to conduct the research or to pursue property rights.

For countries with limited plant proprietary rights, or none at all, important strategic decisions need to be made. On the positive side, if a country has no plant proprietary rights, then there are no legal restrictions on the use or sale of the innovations within that country. Once the plant invention legally enters the country, it can be used freely. On the negative side, private organizations may have a strong reluctance to disclose or market a new invention in that country. Additionally, private organizations probably would not build research facilities or conduct research within that country because adequate forms of property rights are not available.

In conclusion, it is becoming increasingly important to keep informed of developments in plant proprietary rights, and to develop a plan to address these rights. Before starting a lengthy or expensive research program, review the starting materials for any property rights and determine what are the ownership rights of any final products developed.

\section{Literature Cited}

Bent, S.A., et al. 1987. Protecting property rights in biotechnology worldwide. Macmillan, London.

Ihnen, J., et al. 1989. Protecting plant germplasm: Alternatives to patent and plant variety protection. Intellectual property rights associated with plants Amer. Soc. of Agron., Madison, Wis. ASA Spec. Publ. 52. p. 123-143.

Jondle, R.J. 1989. Overview and status of plant proprietary rights. Intellectual property rights associated with plants. Amer. Soc. of Agron., Madison, Wis. ASA Spec. Publ. 52. p. 5-115.

Jondle, R.J. 1992. Review of progress in plant utility patents and PVP, Proc. 46th Annual Corn \& Sorghum Industry Research Conf., American Seed Trade Assn., Chicago. p. 49-57.

Jondle, R.J. 1992. Legal aspects of varietal protection using molecular markers. Applications of RAPD technology to plant breeding. Joint Plant Breeding Symp., 1 Nov. 1992. Minneapolis. p. $50-52$.

Lerch, V.D. 1989. The plant variety protection act: A current look. Seed World 127(7):20-24.

\section{Covernment and aca- demic admini- strators need to consider bow to transfer most appropriately new technology to the commercial environment.}

